\title{
PEMANFAATAN PUPUK HAYATI PADA TANAMAN JAGUNG MANIS UNTUK MENINGKATKAN PENDAPATAN USAHA TANI DI LAHAN RAWA LEBAK
}

\author{
Mahdiannoor $^{1}$, Nurul Istiqomah ${ }^{2}$ dan Purna Kusumayana ${ }^{3}$ \\ ${ }^{1,2}$ Program Studi Agroteknologi \\ ${ }^{3}$ Program Studi Agribisnis \\ Sekolah Tinggi Ilmu Pertanian Amuntai \\ Email : mahdi_186@yahoo.com
}

\begin{abstract}
Problems faced by Mawar Farmers Group Mawar Sari Village and Farmers Group Ingin Maju Pasar Senin Village Amuntai Tengah Sub-District Hulu Sungai Utara Regency South Kalimantan Province is; farmers do not use fertilizer for corn crops, because their assumption that the swamp land lebak fertile enough, the lack of interest of farmers using superior varieties for corn crops and farmers do not have knowledge about good corn cultivation technology in swamp land. From these various problems, we are given solution with counseling and dissemination about introduction and dissemination of the use of biological fertilizer, sweet corn varieties for the land, good corn cultivation technology in swamp land and make demplot of sweet corn plantation with the use of biofertilizer in Pasar Senin Village for convincing and providing concrete evidence to both partners PKM that the use of biological fertilizers is not inferior to the use of chemical fertilizers in corn crops with maximum results. The results of analysis of corn farming after the activity took place the average R / C ratio in the Pasar Senin Village and Mawar Sari Village experienced a decrease caused by several things.
\end{abstract}

Keywords : Fertilizers, corn, swamps, demplot and farming analysis

\section{PENDAHULUAN}

Pengaruh iklim membentuk suatu lahan yang spesifik sifatnya, salah satunya lahan rawa lebak yang pembentukannya dipengaruhi oleh air. Menurut Noor (2007), lahan rawa lebak adalah lahan yang pada periode tertentu (minimal satu bulan) tergenang air dan rejim airnya dipengaruhi oleh hujan, baik yang turun setempat maupun di daerah sekitarnya.

Kabupaten Hulu Sungai Utara merupakan daerah dengan lahan rawa lebak yang mendominasi, sehingga petaninya pun merupakan petani rawa lebak. Lamanya lahan tergenang pada lebak tengahan dan lebak dalam membuat pilihan petani untuk komoditas budidayanya sangat terbatas. Menurut Galib (2010), usahatani jagung di lahan lebak cukup menjanjikan terutama dilihat dari pencapaian hasil sehingga dapat dijadikan alternatif untuk mencukupi keperluan masyarakat terhadap jagung yang terus meningkat setiap tahun. Jagung yang diusahakan di 
lahan lebak awalnya hanya ditujukan untuk konsumsi dalam bentuk tongkol bukan pipilan kering saja.

Masalah utama dalam usahatani di lahan lebak di Kalimantan Selatan adalah kondisi fisik lahan yang cukup berat dengan vegetasi yang cepat tumbuh, ketergantungan dengan kondisi iklim, masalah kekeringan dan kebanjiran, kurangnya tenaga kerja, teknologi budidaya yang masih rendah, kondisi sosial ekonomi petani, pemasaran serta dukungan sarana dan prasarana terutama angkutan yang masih kurang (Muryadi, 1983 dalam Galib, 2010).

Pemilihan Kelompok Tani sebagai mitra dalam kegiatan berdasarkan pertimbangan bahwa anggota kelompok tani adalah masyarakat tani yang lebih mudah untuk menerima hal-hal baru serta dapat menularkan pada petani lainnya. Seperti yang dikatakan Hermanto dan Swastika (2011), bahwa sebagai organisasi sosial masyarakat, kelompok tani berfungsi sebagai wadah belajar-mengajar bagi anggotanya guna meningkatkan pengetahuan, ketrampilan, dan sikap serta tumbuh dan berkembangnya kemandirian dalam berusahatani dengan produktivitas yang meningkat, pendapatan yang bertambah, dan kehidupan yang lebih sejahtera.

Permasalahan yang dihadapi Kelompok Tani Mawar Desa Mawar Sari dan Kelompok Tani Ingin Maju Desa Pasar Senin Kecamatan Amuntai Tengah Kabupaten Hulu Sungai Utara Provinsi Kalimantan Selatan adalah ; petani tidak menggunakan pupuk untuk tanaman jagungnya, karena anggapan mereka bahwa lahan rawa lebak cukup subur, tidak adanya ketertarikan petani menggunakan varietas unggul untuk tanaman jagung dan petani tidak mempunyai pengetahuan tentang teknologi budidaya tanaman jagung yang baik di lahan rawa lebak.

Berdasarkan hal tersebut maka pemanfaatan pupuk hayati pada tanaman jagung manis untuk meningkatkan pendapatan usahatani di lahan rawa lebak menjadi sesuatu kegiatan yang perlu diperkenalkan pada kedua mitra di atas. Setelah selesai kegiatan ini diharapkan mitra ditargetkan untuk dapat menerapkan pemanfaatan pupuk hayati pada tanaman jagung manis untuk meningkatkan pendapatan usahatani di lahan rawa lebak, yang pada akhirnya akan tercipta petani yang kreatif dan inovatif, serta mandiri secara ekonomi. 
Sedangkan luaran yang diharapkan dari kegiatan ini adalah : publikasi ilmiah di jurnal/prosiding, publikasi pada media masa, peningkatan kuantitas dan kualitas hasil tanaman jagung, peningkatan pemahaman dan ketrampilan masyarakat untuk teknologi budidaya dan membuat buku ajar.

\section{METODE PELAKSANAAN}

Pengabdian pada Masyarakat ini dilaksanakan di Desa Mawar Sari tanggal 10 Agustus 2017 dan Desa Pasar Senin tanggal 15 Mei 2017 untuk tahap 1, sedangkan untuk tahap 2 Desa Mawar Sari tanggal 19 Oktober 2017 dan Desa Pasar Senin tanggal 27 Oktober 2017. Kedua desa terletak di Kecamatan Amuntai Tengah Kabupaten Hulu Sungai Utara Provinsi Kalimantan Selatan.

Pengusul terdiri atas 3 orang dosen STIPER Amuntai yang berasal dari program studi Agroteknologi sebanyak 2 orang dan program studi Agribisnis 1 orang. Mitranya adalah 2 kelompok tani yang bertempat tinggal di Desa Mawar Sari dan Desa Pasar Senin, setiap kelompok tani mempunyai anggota 20 orang.

Agar pengabdian pada masyarakat ini dapat menghasilkan luaran yang diharapkan maka digunakan metode penyuluhan langsung yang mengkombinasikan antara ceramah dan demontrasi plot. Ceramah ; dilakukan dalam dua tahap yaitu 1) sebelum demplot dibuat, dan 2) sesudah demplot dan jagung petani panen dengan diskusi dan evaluasi pada anggota kelompok tani. Pada metode ini pengusul bertindak sebagai penyampai informasi (penyuluh) sedangkan kelompok tani merupakan penerima informasi. Demontrasi Plot dilakukan dengan penanaman jagung manis yang menggunakan pupuk hayati di Desa Pasar Senin.

\section{HASIL DAN LUARAN YANG DICAPAI}

Hasil

Kegiatan penyuluhan dan sosialisasi ini terbagi menjadi dua tahap yaitu : tahap pertama perkenalan teknologi budidaya jagung manis dengan pupuk hayati untuk Kelompok Tani Ingin Maju Desa Pasar Senin dilaksanakan pada tanggal 15 Mei 2017 dan Kelompok Tani Mawar Desa Mawar Sari dilaksanakan pada tanggal 27 Juli 2017. Pada tahap pertama ini selain dilakukan penyuluhan dan sosialisasi mengenai teknologi budidaya 
jagung manis Varietas Bonanza $F_{1}$ dengan menggunakan pupuk hayati Ultragen juga dilakukan penghitungan analisis usaha tani jagung yang selama ini sudah mereka lakukan dengan hasil analisis rata-rata $\mathrm{R} / \mathrm{C}$ rasio layak dan penyerahan bantuan benih jagung dan pupuk hayati yang akan digunakan para petani dan selanjutnya akan dilakukan evaluasi pada penyuluhan tahap kedua.

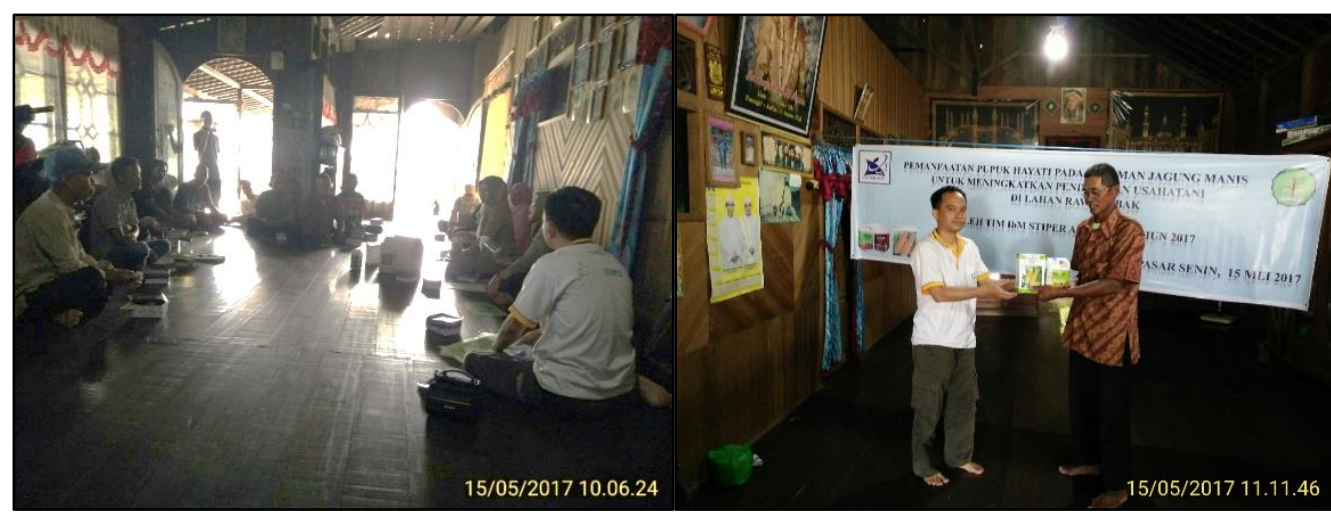

Gambar 1. Penyuluhan dan penyerahan bantuan benih dan pupuk hayati di Desa Pasar Senin

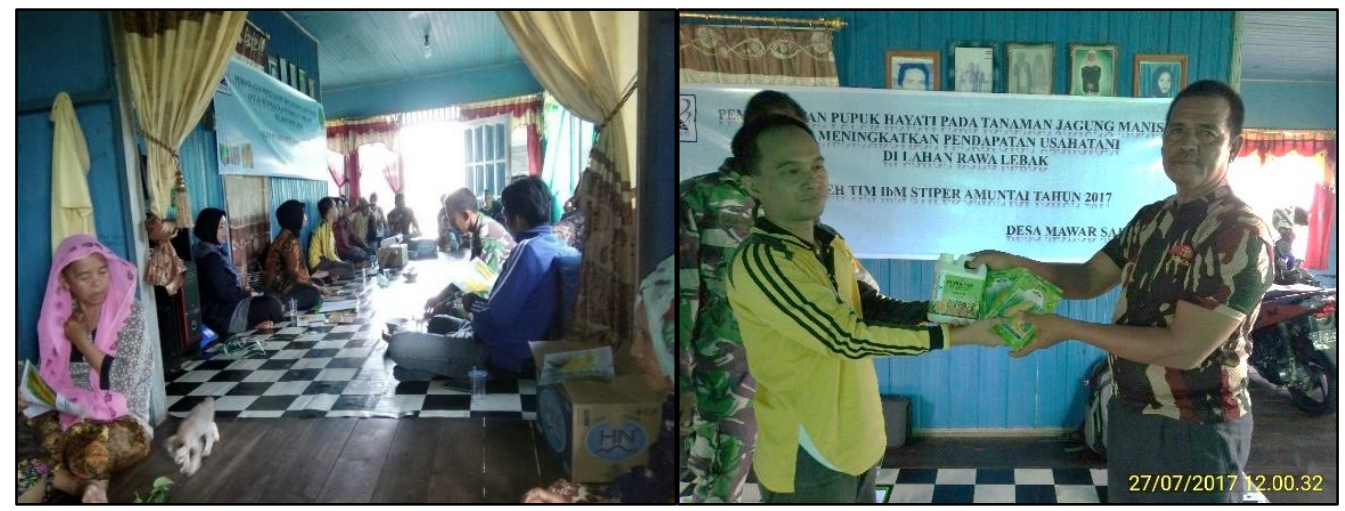

Gambar 2. Penyuluhan dan penyerahan bantuan benih dan pupuk hayati di Desa Mawar Sari

Untuk meyakinkan para petani menggunakan pupuk hayati maka dilakukan kegiatan demplot percobaan tanaman jagung yang berlokasi di Desa Pasar Senin RT IV, pada demplot dilakukan dua perlakuan tanaman jagung yaitu satu perlakuan dipupuk dan satu lagi tidak dipupuk. Dari demplot dilapangan menunjukkan pertumbuhan dan hasil tanaman jagung yang sangat berbeda, dimana penggunaan pupuk hayati dengan frekuensi sampai 7 kali pemberian sampai menjelang tanaman jagung berbunga menunjukkan hasil panen jagung hampir sama dengan 
penggunaan pupuk kimia, yaitu t.ha ${ }^{-1}$.

menunjukkan potensi hasil sampai 14

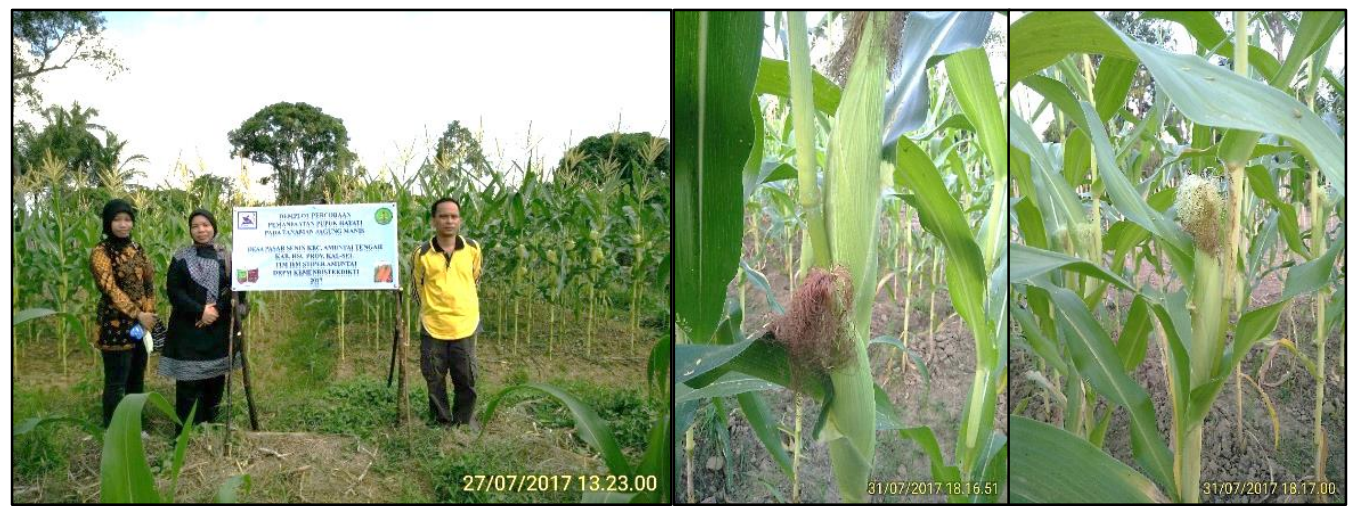

Gambar 3. Demplot tanaman jagung manis di Desa Pasar Senin

Penyuluhan tahap kedua untuk

Kelompok Tani Ingin Maju Desa Pasar

Senin dilakukan pada tanggal 27

Oktober 2017 dan Kelompok Tani

Mawar Desa Mawar Sari lebih awal lagi yaitu tanggal 19 Oktober 2017. Pada tahap kedua ini ada beberapa permasalahan dalam kegiatan petani menanam jagung antara lain masih ada petani tidak melakukan pengolahan tanah, menanam benih jagung lebih dari satu biji tiap lobang tanam, pupuk hayati yang tidak digunakan tetapi tetap menggunakan pupuk kimia serta berbagai masalah lain yang pada intinya ternyata petani kita masih ingin fleksibel menggunakan pupuk kimia tanpa melihat bahwa produk hasil pertanian yang menggunakan pupuk kimia kurang aman dan ramah bagi konsumen serta lingkungan sendiri. Selain tanya jawab dengan para petani juga dilakukan penghitungan analisis usaha tani jagung yang menggunakan

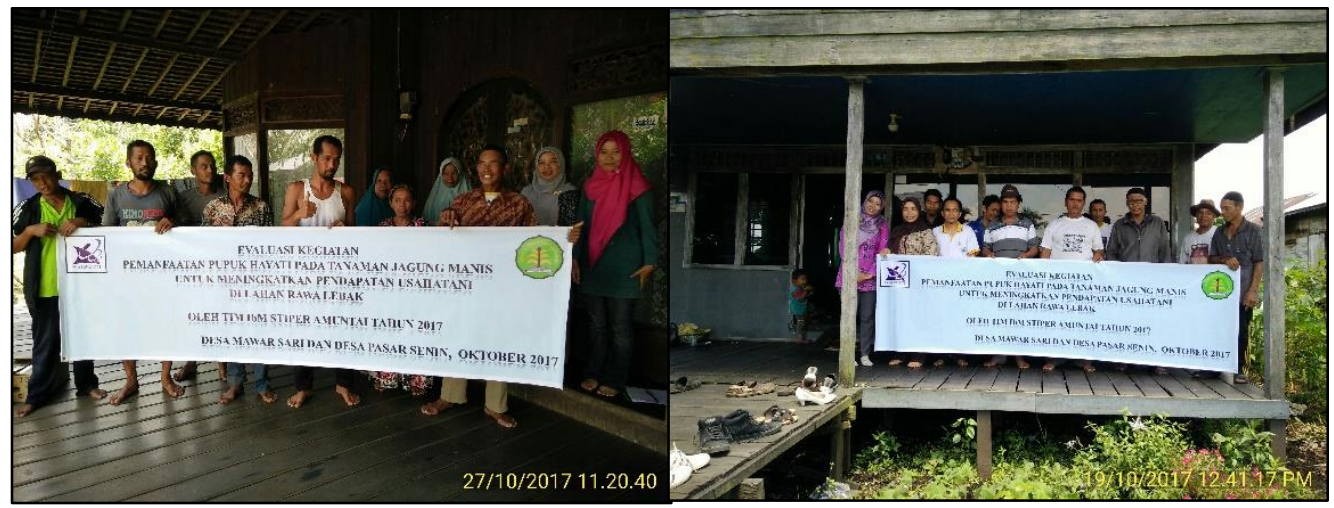

Gambar 4. Photo bersama setelah evaluasi kegiatan di 2 desa mitra selesai 
pupuk hayati yang sudah mereka lakukan dengan hasil untuk Kelompok Tani Ingin Maju Desa Pasar Senin terjadi sedikit kenaikan rata-rata nilai $\mathrm{R} / \mathrm{C}$ rasio sebelum kegiatan yaitu 2 dan setelah kegiatan menjadi 2,2, sedangkan untuk Kelompok Tani Desa Mawar Desa Mawar Sari malah terjadi penurunan rata-rata nilai $\mathrm{R} / \mathrm{C}$ rasio sebelum kegiatan adalah 3 dan setelah kegiatan menjadi 1,8. Penurunan ini terjadi disebabkan beberapa faktor antara lain luas tanam jagung yang berkurang dari tahun sebelumnya karena petani di Desa Mawar Sari tidak bisa lagi leluasa membakar lahan pertanian seperti tahun sebelumnya karena pengawasan yang ketat dari pihak yang terkait serta kondisi iklim musim kemarau namun curah hujannya cukup tinggi.

\section{Luaran Yang Dicapai}

Luaran yang tercapai dalam program kemitraan masyarakat ini adalah :

1. Artikel ilmiah pada Jurnal Pengabdian Masyarakat Al Ikhlas Vol. 03 No. 2 April 2018 Universitas Islam Kalimantan MAB Banjarmasin (https://ojs.uniskabjm.ac.id/index.php/AIJP).
2. Publikasi pada Harian Banjarmasin Post Edisi 25 Nopember 2017 halaman 12 dengan judul “ Petani Ketagihan Pupuk Hayati” No. 115Th. XLVII/ISSN 0215-2987 dan pada

banjarmasin.tribunnews.com/20 17/11/24/kembangkanjjagungmanis-dengan-pupuk hayati-dilahan-rawa-lebak-petani-takperlu-beli-pupuk serta pada laman pribadi penulis http://agroswamp.com/2017/10/ perkenalkan-teknologibudidaya-jagung-manis-denganpupuk-hayati-di-lahan-rawalebak/.

3. Peningkatan ketrampilan mitra diperoleh dengan mengajukan kuisioner serta pengamatan langsung dilapangan.

4. Peningkatan kualitas dan kuantitas hasil tanaman jagung diperoleh dengan mengajukan kuisioner analisis usaha tani dan menganalisis hasilnya dengan MS Excel baik pada tahap 1 maupun tahap 2 .

5. Draft buku ajar sesuai apa yang di ajar oleh penulis. 


\section{KESIMPULAN DAN SARAN}

\section{Kesimpulan}

Berdasarkan hasil dan analisa pengabdian pada masyarakat pemanfaatan pupuk hayati untuk tanaman jagung manis untuk meningkatkan pendapatan usaha tani di lahan rawa lebak ini dapat diambil kesimpulan sebagai berikut :

1. Introduksi jagung manis dan pupuk hayati dapat berlangsung dengan baik.

2. Hasil analisis usaha tani jagung di Desa Pasar Senin rata-rata $\mathrm{R} / \mathrm{C}$ ratio mengalami kenaikan dan Desa Mawar Sari rata-rata $\mathrm{R} / \mathrm{C}$ ratio mengalami penurunan setelah kegiatan berlangsung.

\section{Saran}

Untuk kelancaran kegiatan maka peran serta petani sangat penting sehingga diperlukan metode pendekatan yang baik untuk mendapatkan informasi yang akurat dan hasil pengabdian yang optimal.

\section{DAFTAR PUSTAKA}

Hermanto dan Swastika, D.K.S. Penguatan Kelompok Tani : Langkah Awal Peningkatan Kesejahteraan Petani. Analisis Kebijakan Pertanian. Volume 9 No. 4 hal : 371-390.

Noor, M. 2007. Rawa Lebak ; Ekologi, Pemanfaatan, dan Pengembangannya. PT. Rajagrapindo Persada. Jakarta.

Galib, R. 2010. Potensi Usaha Tani Jagung Di Lahan Rawa Lebak Kalimantan Selatan. Prosiding Pekan Serelia Nasional 2010.

\section{UCAPAN TERIMAKASIH}

Direktorat Riset dan Pengabdian Masyarakat Direktorat Jenderal Penguatan Riset dan Pengembangan Kementerian Riset, Teknologi, dan Pendidikan Tinggi. Sesuai dengan Perjanjian Penugasan Pelaksanaan Program Pengabdian Pada Masyarakat Nomor : 105/SP2H/PPM/DRPM/2017, tanggal $\quad 3 \quad$ April 2017. 